\title{
Evaluation of quality of life related to melasma
}

Avaliação de qualidade de vida relacionada ao melasma

Evaluación de calidad de vida relacionada al melasma

Camila Fernandes Pollo' ${ }^{1}$, Helio Amante Miot², Silmara Meneguin ${ }^{1}$

ORCID IDs

Pollo CF (D) https://orcid.org/0000-0003-0264-5841

Miot HA (1D https://orcid.org/0000-0002-2596-9294

Meneguin S (1) https://orcid.org/0000-0003-3853-5134

\section{HOW TO CITE}

Pollo CF; Miot HA; Meneguin S. Evaluation of quality of life related to melasma. ESTIMA, Braz. J. Enterostomal Ther., 16:e1518. doi: 10.30886/estima.v16.362.

\begin{abstract}
Objective: To synthesize the scientific production about quality of life related to melasma and to analyze the instruments used to evaluate the construct. Method: Integrative revision with search in Web of Science databases, Lilacs, PubMed, Scopus, Google Scholar and Embase. All articles published in the literature up to 2013 were included. Results: The sample consisted of 26 articles. Most of the research was realized in the United States of America (30.7\%), followed by Brazil (38.4\%) and South Korea (38.4\%). The intervention studies were emphasized (57.5\%), using Melasma Quality of Life Scale (MELASQol) as a specific instrument. Conclusion: This review allowed to identify that the assessment of quality of life related to melasma has been widely discussed in the literature. As for the instruments used to evaluate the construct, there is only one specific, translated and validated in several countries, but whose development did not follow the classic stages of psychometry.
\end{abstract}

DESCRIPTORS: Melanosis; Quality of life; Nursing.

\footnotetext{
"Universidade Estadual Paulista "Júlio de Mesquita Filho" - Faculdade de Medicina de Botucatu - Departamento de Enfermagem Botucatu/SP - Brazil.

¿Universidade Estadual Paulista "Júlio de Mesquita Filho" - Faculdade de Medicina de Botucatu - Departamento de Dermatologia e Radioterapia - Botucatu/SP - Brazil.

Corresponding author: Silmara Meneguin | Universidade Estadual Paulista "Júlio de Mesquita Filho" - Faculdade de Medicina de Botucatu - Departamento de Enfermagem | Distrito de Rubião Júnior s/n - ZIP Code: 18618-970 - Botucatu/SP - Brazil | E-mail: silmeneguin@fmb.unesp.br

Received: Maio 18, 2016| Accepted: Sept. 11, 2017
} 


\section{RESUMO}

Objetivo: Sintetizar a produção científica sobre qualidade de vida relacionada ao melasma e analisar os instrumentos utilizados para avaliação do constructo. Método: Revisão integrativa com busca nas bases de dados Web of Science, Lilacs, Pubmed, Scopus, Google Scholar e Embase. Foram incluídos todos os artigos publicados na literatura até 2013. Resultados: A amostra constituiu-se de 26 artigos. A maioria das pesquisas foi realizada nos Estados Unidos da América (30,7\%), seguidos pelo Brasil (38,4\%) e pela Coreia do Sul (38,4\%). Destacaram-se os estudos de intervenção (57,5\%), utilizando como instrumento específico a Melasma Quality of Life Scale (MELASQol). Conclusão: Esta revisão permitiu identificar que a avaliação da qualidade de vida relacionada ao melasma tem sido um tema amplamente abordado na literatura. No que se refere aos instrumentos utilizados para avaliação do constructo, há apenas um específico, traduzido e validado em diversos países, mas cujo desenvolvimento não seguiu as etapas clássicas da psicometria.

DESCRITORES: Melanose; Qualidade de vida; Enfermagem.

\section{RESUMEN}

Objetivo: Sintetizar la producción científica sobre calidad de vida relacionada al melasma y analizar los instrumentos utilizados para evaluación del constructo. Método: Revisión integradora que busca en las bases de datos Web of Science, Lilacs, Pubmed, Scopus, Google Scholar y Embase. Se incluyeron todos los artículos publicados en la literatura hasta 2013. Resultados: La muestra está constituida por 26 artículos. La mayoría de las investigaciones se realizó en los Estados Unidos de América (30,7\%), seguidos por Brasil (38,4\%) y por Corea del Sur (38,4\%). Se destacaron los estudios de intervención (57,5\%), utilizando como instrumento específico a Melasma Quality of Life Scale (MELASQol). Conclusión: Esta revisión permitió identificar que la evaluación de la calidad de vida relacionada al melasma ha sido un tema ampliamente abordado en la literatura. En lo que se refiere a los instrumentos utilizados para evaluación del constructo, hay solo uno específico, traducido y validado en diversos países, pero cuyo desarrollo no siguió las etapas clásicas de la psicometría.

DESCRIPTORES: Melanosis; Calidad de vida; Enfermería.

\section{INTRODUCTION}

Melasma is a recurrent chronic pigmentary disorder, characterized by asymptomatic and symmetrical hyperpigmented macules in the skin due to the local increase of melanogenesis. It affects millions of people around the world ${ }^{1}$.

It mainly affects women of fertile age, and photoexposed areas are the most affected, preferably face ${ }^{2}$. Hispanics and Asians have a higher incidence ${ }^{3}$, in addition people that live in areas of intense solar radiation, such as India, Pakistan, the Middle East and the Mediterranean area ${ }^{4}$. The prevalence of melasma in Latin American women varies from 1.5 to $33.3 \%$ and the estimate among pregnant Latin women is between 50 and $80 \%^{5-8}$.

The sunlight and genetic predisposition are the most important etiological factors of melasma, as well as racial characteristics, medications, cosmetics and endocrinopathies ${ }^{4,9-10}$.

Although in Brazil there are no population-based studies to evaluate the prevalence of the disease, in dermatological clinics, pigmentary dermatoses represent the third cause of appointments (8.4\%), varying among age groups, genders and the different regions of the country ${ }^{11}$. In an investigation with public institution employees from the countryside of Brazil, melasma was identified in $22 \%$ of them ${ }^{12}$.

Melasma, although asymptomatic, maximizes its impact on body image and interpersonal relationships, interfering with the perception of quality of life. However, to evaluate the quality of life is admittedly a complex task, because it is an abstract concept, subjective and for which there is no consensual definition ${ }^{13}$.

In view of these considerations, there is interest in developing an integrative review of the scientific literature on quality of life related to melasma (QLRM). Such research is justified for knowledge and interpretation of the production on the theme with the purpose of contributing to the development of future researches.

\section{OBJECTIVES}

In view of this question, this study has the purposes to synthesize the scientific production on QLRM and to analyze the instruments used for the evaluation of the construct.

\section{METHODS}

An integrative review study was realized, operationalized in the following steps: identification of the hypothesis 
or guiding question, followed by the search for the descriptors or keywords; selection of sampling; categorization of studies; evaluation of studies; discussion and interpretation of results; presentation of the integrative review and synthesis of knowledge ${ }^{14}$. The search was guided by the following question: What are the instruments available in the literature to perform QLRM evaluation?.

The Web of Science, Lilacs, Medline, Scopus, Google Scholar and Embase databases were used, using the descriptors Melasma, Melanosis and Chloasma, which were combined, using the "and" Boolean connector, with the descriptor Quality of life.

The inclusion criteria were: research articles indexed in the databases researched and published up to the year
2013. The data were categorized and discussed according to the objectives of the integrative review.

\section{RESULTS}

A total of 1.416 articles about the theme were identified. Of these, 26 were included in this study. Almost all of them were presented in the English language and 17 papers (65.46\%) were observed and indexed in more than one database.

In relation to the year of publication, a greater number of articles of 2011 were found, being five (19.2\%), followed by those of 2012,2009 and 2008, four in each year (46.1\%), as can be seen in Table 1. Most of the QLRM surveys

Table 1. Summary of articles included in the integrative review. Botucatu, Sao Paulo, Brazil, 2014.

\begin{tabular}{|c|c|c|c|c|}
\hline No. & Title & Author & Journal/year & Instrument \\
\hline 1 & Quality of life in patients of melasma. & Raafia A, et al & $\begin{array}{l}\text { J Pakistan } \\
\text { Assoc } \\
\text { Dermatol/2013 }\end{array}$ & DLQ। \\
\hline 2 & $\begin{array}{l}\text { Usefulness of melasma quality of life scale } \\
\text { (MELASQOL) when evaluating the quality of } \\
\text { life in Korean melasma patients }\end{array}$ & Kim HY,et al & $\begin{array}{c}\text { Korean J } \\
\text { Dermatol/2013 }\end{array}$ & $\begin{array}{l}\text { MELASQOl / } \\
\text { DLQI }\end{array}$ \\
\hline 3 & $\begin{array}{l}\text { Interest of corrective makeup in the } \\
\text { management of patients in dermatology }\end{array}$ & Seité $S$, et al & $\begin{array}{l}\text { Clin Cosmet } \\
\text { Investig } \\
\text { Dermatol/2013 }\end{array}$ & DLQI \\
\hline 4 & $\begin{array}{l}\text { Change of quality of life after melasma } \\
\text { treatment }\end{array}$ & Kang $\mathrm{H}$, et al & $\begin{array}{l}\text { Korean J } \\
\text { Dermatol/2012 }\end{array}$ & MELASQol \\
\hline 5 & $\begin{array}{l}\text { Preventing melasma recurrence: prescribing } \\
\text { a maintenance regimen with an effective } \\
\text { triple combination cream based on long- } \\
\text { standing clinical severity }\end{array}$ & Arellano I, et al & $\begin{array}{c}\text { J Eur Acad } \\
\text { Dermatol } \\
\text { Venereol/2012 }\end{array}$ & MELASQol \\
\hline 6 & $\begin{array}{l}\text { A randomized double-blind placebo } \\
\text { controlled study evaluating the effectiveness } \\
\text { and tolerability of oral Polypodium } \\
\text { leucotomos in patients with melasma }\end{array}$ & Martin LK, et al & $\begin{array}{c}\text { J Am Acad } \\
\text { Dermatol/2012 }\end{array}$ & MELASQol \\
\hline 7 & $\begin{array}{l}\text { Photoprotection, melasma and quality of life } \\
\text { in pregnant women }\end{array}$ & Purim KSM, et al & $\begin{array}{l}\text { Rev Bras Ginec } \\
\text { Obst/2012 }\end{array}$ & DLQ \\
\hline 8 & $\begin{array}{l}\text { Measuring melasma patients' quality of life } \\
\text { using willingness to pay and time trade-off } \\
\text { methods in a Thai population }\end{array}$ & $\begin{array}{l}\text { Leeyaphan C, } \\
\quad \text { et al }\end{array}$ & $\begin{array}{c}\text { BMC } \\
\text { Dermatol/2011 }\end{array}$ & MELASQol \\
\hline 9 & $\begin{array}{l}\text { Evaluation of quality of life improvement } \\
\text { in melasma patients, measured by the } \\
\text { MELASQol following the use of a botanical } \\
\text { combination based on Bellis perennis, } \\
\text { Glycyrrhiza glabra and Phyllanthus emblica }\end{array}$ & Costa A, et al & $\begin{array}{l}\text { Surg Cosmet } \\
\text { Dermatol/2011 }\end{array}$ & MELASQol \\
\hline
\end{tabular}


Table 1. Continuation...

No. Title

Double-blind randomized study of 5\% and

10

$10 \%$ retinoic acid peels in the treatment of

melasma: clinical evaluation and impact on

the quality of life

A comparative study of the safety and

efficacy of 75\% mulberry (Morus alba) extract

11 oil versus placebo as a topical treatment

for melasma: a randomized, single-blind, placebo-controlled trial

12

Korean red ginseng powder in the treatment of

melasma: an uncontrolled observational study

Lactic acid chemical peel in the treatment of

13 melasma: clinical evaluation and impact on quality of life

14 Covering foundation improves quality of life in patients with melasma

Alvin $\mathrm{G}$, et al

J Drugs

Dermatol/2011

MELASQOI

Song $M$, et al $\quad$ Ginseng
Res/2011

MELASQOI

Magalhães GM, Surg Cosmet et al

Dermatol/2010

Skindex-16

Morita Y, et al

Hifu/2009

MELASQOI

15 Clinical efficacy of 25\% L-ascorbic acid

(C'ensil) in the treatment of melasma

Hwang SW, et al

J Cutan Med

Surg/2009

DLQI

The prevalence of melasma and its

16 association with quality of life among adult male Latino migrant workers

Pichardo $\mathrm{R}_{\text {, et al }}$

Int J
Dermatol/2009

MELASQOI

Effectiveness, safety, and effect on quality of

17 life of topical salicylic acid peels for treatment

of post inflammatory hyperpigmentation in dark skin

18 Prevalence of pigmentary disorders and their impact on quality of life: a prospective cohort study

19 Effect of melasma on quality of life in a sample of women living in southern Brazil

20 Skin-lightening effects of a new face care product in patients with melasma

Joshi SS, et al Dermatol

Surg/2009

DLQI

Taylor A, et al $\quad \begin{aligned} & \text { C Cosmet } \\ & \text { Dermatol/2008 }\end{aligned}$

Não cita

J Eur Acad

Freitag FM, et al Dermatol

Venereol/2008

Scherdin $U$, et al $\quad \begin{gathered}\text { J Cosmet } \\ \text { Dermatol/2008 }\end{gathered}$

Scherdin U, et al $\begin{gathered}\mathrm{J} \text { Cosmet } \\ \text { Dermatol/2008 }\end{gathered}$

MELASQOI

The association of dermatologist-diagnosed

21 and self-reported skin diseaseswith skin-

related quality of life in Latino migrant

Quandt SA, et al

Int J

Dermatol/2008

MELASQOI farmworkers

22 Quality of life in melasma

Cho $\mathrm{TH}$, et al

Korean

Dermatol/2007

MELASQOI

Effectiveness of a new depigmenting trio,

Melanex® Trio in melasma: clinical and

23

biometrological results, quality of life, image analysis

24 Correlates of health-related quality of life in women with severe facial blemishes

Levy J-L, et al $\quad \begin{gathered}\text { Nouv } \\ \text { Dermatol/2006 }\end{gathered}$

MELASQOI

Improved quality of life with effective

25

treatment of facial melasma: the pigment trial

26

Predictors of health-related quality of life in

women with melasma

Balkrishnan R, et al

Int J

Dermatol/2004

Skindex-16

Balkrishnan $\mathrm{R}$, et al

J Drugs

Dermatol/2004

Not mentioned

Balkrishnan R, J Cosmet et al

Dermatol/2003 
were performed in the United States (30.7\%), followed by Brazil and South Korea, with five in each country (38.4\%) and two (7.7\%) in France, Pakistan, Germany, Thailand, the Philippines and Japan presented only one publication (23.0\%). Intervention studies (57.5\%) and cross-sectional studies (42.3\%) were highlighted.

According to the articles included in the study, 14 (53.8\%) used the Melasma Quality of Life Scale instrument (MELASQol); six (23.0\%), the Dermatology Life Quality Index (DLQI); three (11.5\%), Skindex-16; and one (3.8\%), MELASQol and DLQI, simultaneously. Two articles (7.7\%) did not mention the instrument used. With regard to these instruments, they were classified into two categories: a specific instrument to evaluate QLRM and specific instruments to evaluate quality of life in dermatology.

\section{Specific instrument to evaluate quality of life related to melasma}

In 2003, an Indian researcher and his collaborators developed and validated MELASQ ${ }^{15}$, a specific instrument composed of ten items to evaluate the repercussion of melasma in the emotional state, social relations and daily activities. The English version of MELASQol showed high internal consistency, validity and discriminatory power when compared to the general questionnaires for evaluation of quality of life in dermatology, Skindex-16 16 and DLQI ${ }^{17}$.

In this perspective, the results demonstrated that MELASQol is a valid and reliable instrument that can be used to monitor the effect that melasma has on patients' quality of life. This instrument has been widely used and has been translated and validated for several countries.

\section{Specific instruments to evaluate quality of life in dermatology}

The DLQI is a generic instrument for dermatological diseases. It was validated for the purpose to allow a simple, compact and uniform evaluation of patients with dermatological diseases in general. It is an instrument composed of ten items, divided into six domains: symptoms and feelings, daily activities, leisure, work/school, personal relationships and treatment ${ }^{17}$.
The Skindex was another generic instrument cited in the articles. This instrument consists of 61 items, divided into eight domains: cognitive, social, depression, fear, embarrassment, anger, physical discomfort and physical limitations. There is a simplified version, Skindex-29, which has 29 items, divided into three domains: symptoms, functionality and emotions. Skindex-16, used in the studies identified in this study, presents three domains and a reduced number of items ${ }^{16}$.

\section{DISCUSSION}

Melasma is characterized by irregular melanic pigmentation that affects exposed areas, such as the face, especially women in fertile age, which maximizes its impact on body image and interpersonal relationships. The social-emotional discomfort caused by patches negatively affects the perception of quality of life due to the darkened appearance of the skin ${ }^{18}$.

It is a recurrent disease and can be prevented, restricting excessive sun exposure with environmental education and the use of sun filters ${ }^{8}$. In this research, the results showed that there was the concern in evaluate the quality of life in different sociocultural contexts in the last decades, but also that there is restriction to a single instrument available to evaluate the quality of life of patients with melasma (MELASQol).

The data analyzed showed that the United States of America ${ }^{2,6,19}$, Brazil ${ }^{18,20}$ and South Korea ${ }^{21,22}$ were the publication leaders about the theme. The other articles are distributed between Europe and $\mathrm{Asia}^{23,24}$. The studies included in this research were mostly developed in a single country, with the exception of only one, realized between Brazilian and Mexican institutions ${ }^{25}$.

Regarding the type of methodology applied in the selected articles in this review, it was observed that 15 (57.7\%) were intervention studies and, of these, seven (26.9\%) were randomized controlled clinical testing. Regarding the studied population, it was observed that 14 studies (53.8\%) did not mention the gender of the interviewees, ten (38.4\%) were performed with only women participation, one (3.9\%) was made only with men and one (3.9\%) researched both genders.

The conduction of studies preferentially with women is linked to the pathophysiology of this condition, in 
which the appearance of lesions occurs, especially after exposure to sexual steroids, such as oral contraceptives, pregnancy, hormone replacement therapy and during fertile period ${ }^{26}$.

However, a study realized with men with melasma showed that they are also affected, although in a lesser extent. Facial patches tend to cause embarrassing situations due to the unpleasant appearance, as well as the social stigma attached to the fact that it is a disease that affects pregnant women ${ }^{2}$. Another population-based study showed that, unlike women, men did not use makeup to camouflage the patch, which worsened the quality of life compared to men without pigment disorders 6 .

A recent study, conducted with 515 public university employees from the state of São Paulo, Brazil, showed that melasma was more frequently associated with women (odds ratio $[\mathrm{OR}]=8.0, \mathrm{p}<0.01)$. In this study, the occurrence of melasma was $34 \%$ in women and $6 \%$ in men ${ }^{12}$.

Regarding the instruments used to evaluate the QLRM, the only one identified in this research, MELASQol, did not follow the construction and validation steps established in the literature. First, the authors did not construct the questions, that is, they used seven questions from the Skindex-16 questionnaire, a generic instrument to evaluate the quality of life of patients with dermatological diseases in general, and three from another questionnaire to evaluate color changes skin and not referenced by the author.

In addition, there were no analyzes of the test-retest of the instrument in its validation process, since this raises questions regarding the reliability of the instrument, although the original English version had high internal consistency, validity and discriminatory power, when compared to other questionnaires. Although melasma is a prevalent disease in women, men were not included in the validation process, which could have contributed to the universalization of the use of the questionnaire in clinical studies, besides exploring characteristics related to this genre.

It should be noted that, despite the simplicity of the application of an instrument of only ten items, it does not contemplate a stratification of the impact of melasma on quality of life, which makes it difficult to dimension the phenomenon in clinical practice, as well as in clinical testing. In addition, MELASQol uses only three items to represent psychological aspects resulting from melasma, in comparison to the approach of social relations, leisure, profession and physical appearance of the disease.

In spite of all limitations in the construction and validation process, the instrument was translated and validated for Brazilian Portuguese in $2006^{28}$ (MELASQol-BP), from the English version. In this multicenter study, 300 participants from five Brazilian geographic regions were included in the survey. The analysis showed a significant impact of the disease on the appearance of the skin, with $65 \%$ of interviewees reported discomfort with the patches all the time or most of the time, $55 \%$ cited frustration and $57 \%$ mentioned embarrassment about the condition of their skin. 43\% of patients did not feel attractive but dirty due to this condition. The results demonstrated that MELASQol-BP is a valid instrument and can be used to evaluate the quality of life in Brazilian patients with melasma.

However, new QLRM specific questionnaires should be developed and validated in order to compare their properties with MELASQol and to characterize aspects related to the impact of melasma on patients.

\section{CONCLUSION}

This review allowed us to identify that there is only one QLRM evaluation instrument, MELASQol, whose development and validation did not follow the classic stages of psychometry.

In the face of gaps and inconsistencies presented in relation to MELASQol, the importance of conducting future research that has as a proposal the development of new instruments for the evaluation of QLRM was evidenced. In addition, it is expected that these will allow to measure the impact on the quality of life inflicted by melasma, making possible its use in assistance, teaching and research.

\section{AUTHOR'S CONTRIBUTION}

Conceptualization, Pollo CF; Meneguin S and Miot HA; Methodology, Pollo CF; Meneguim S and Miot HA; Investigation, Pollo CF; Writing - First version, Pollo CF; Writing - Review \& Editing, Meneguin S and Miot HA; Supervision, Meneguin S. 


\section{REFERENCES}

1. Sheth VM, Pandya AG. Melasma: a comprehensive update: part I. J Am Acad Dermatol. 2011;65(4):689-97. doi: 10.1016/j.jaad.2010.12.046

2. Martin LK, Caperton C, Woolery-Lloyd H, Avashia N. A randomized double-blind placebo controlled study evaluating the effectiveness and tolerability of oral Polypodium leucotomos in patients with melasma. J Am Acad Dermatol. 2012;66(4):AB21. doi: 10.1016/j.jaad. 2011.11.096

3. Nicolaidou E, Antoniou C, Katsambas AD. Origin, clinical presentation, and diagnosis of facial hypermelanoses. Dermatol Clin. 2007;25(3):321-6. doi: 10.1016/j.det.2007. 05.002

4. Rathi SK, Achar A. Melasma: a clinico-epidemiological study of 312 cases. Indian J Dermatol. 2011;56(4):380-2. doi: 10.4103/0019-5154.84722

5. Urasaki MBM. Alterações fisiológicas da pele percebidas por gestantes assistidas em serviços públicos de saúde. Acta Paul Enferm. 2010;23(4):519-25. doi: 10.1590/s010321002010000400012

6. Pichardo R, Vallejos Q, Feldman SR, Schulz MR, Verma A, Quandt SA, et al. The prevalence of melasma and its association with quality of life among adult male Latino migrant workers. Int J Dermatol. 2009;48(1):22-6. doi: 10.1111/j.1365-4632.2009.03778.x

7. Bolanca I, Bolanca Z, Kuna K, Vukovic A, Tuckar N, Herman $\mathrm{R}$, et al. Chloasma - the mask of pregnancy. Coll Antropol. 2008;32(Suppl 2):139-41.

8. Lakhdar H, Zouhair K, Khadir K, Essari A, Richard A, Seité S, et al. Evaluation of the effectiveness of a broad-spectrum sunscreen in the prevention of chloasma in pregnant women. J Eur Acad Dermatol Venereol. 2007;21(6):73842. doi: 10.1111/j.1468-3083.2007.02185.x

9. Hexsel D, Rodrigues TC, Dal'Forno T, Zechmeister-Prado D, Lima MM. Melasma and pregnancy in southern Brazil. J Eur Acad Dermatol Venereol. 2009;23(3):367-8. doi: 10.1111/j.1468-3083.2008.02885.x

10. Miot LDB, Miot HA, Silva MG, Marques MEA. Fisiopatologia do melasma. An Bras Dermatol. 2009;84(6):623-35. doi: 10.1590/s0365-05962009000600008

11. Sociedade Brasileira de Dermatologia. Perfil nosológico das consultas dermatológicas no Brasil. An Bras Dermatol. 2006;81(6):549-58. doi: 10.1590/s0365-05962006000600 006

12. Ishiy PS, Silva LR, Penha MA, Handel AC, Miot HA. Skin diseases reported by workers from UNESP campus at Rubião Jr, Botucatu-SP (Brazil). An Bras Dermatol. 2014;89(3):529-31. doi: 10.1590/abd1806-4841.20142 875

13. Fleck MPA, Louzada S, Xavier M, Chachamovich E, Vieira G, Santos L, et al. Aplicação da versão em português do instrumento abreviado de avaliação da qualidade de vida "WHOQOL-bref". Rev Saúde Pública. 2000;34(2):178-83. doi: 10.1590/s0034-89102000000200012

14. Whittemore R, Knafl K. The integrative review: updated methodology. J Adv Nurs. 2005;52(5):546-53. doi: 10.1111/j.1365-2648.2005.03621.x
15. Balkrishnan R, McMichael AJ, Camacho FT, Saltzberg F, Housman TS, Grummer S, et al. Development and validation of a health-related quality of life instrument for women with melasma. Br J Dermatol. 2003;149(3):572-7. doi: 10.1046/j.1365-2133.2003.05419.x

16. Chren MM, Lasek RJ, Quinn LM, Mostow EN, Zyzanski SJ. Skindex, a quality-of-life measure for patients with skin disease: reliability, validity, and responsiveness. J Invest Dermatol. 1996;107(5):707-13. doi: 10.1111/1523-1747. ep12365600

17. Finlay AY, Khan GK. Dermatology Life Quality Index (DLQI) - a simple practical measure for routine clinical use. Clin Exp Dermatol. 1994;19:210-6. doi: 10.1111/j.13652230.1994.tb01167.x

18. Purim KSM, Avelar MFS. Fotoproteção, melasma e qualidade de vida em gestantes. Rev Bras Ginecol Obstet. 2012;34(5):228-34. doi: 10.1590/s0100-720320120005 00007

19. Balkrishnan R, Housman TS, Allen B, McMichael AJ. Predictors of health-related quality of life in women with melasma. J Cosmet Dermatol. 2003;16(4):25-9.

20. Freitag FM, Cestari TF, Leopoldo LR, Paludo P, Boza JC. Effect of melasma on quality of life in a sample of women living in southern Brazil. J Eur Acad Dermatol Venereol. 2008;22(6):655-62. doi: 10.1111/j.1468-3083. 2007.02472.x

21. Kang H, Baek J, Roh J, Lee J. Change of quality of life after melasma treatment. Korean J Dermatol. 2012;50(7):579-83.

22. Cho, T.-H., Hong, S.-B., Ryou, J.-H., Lee, MH. Quality of life in melasma. Korean J Dermatol. 2007;45(3):232-6.

23. Raafia A, Shahbaz A, Muhammad N, Kazmi AH. Quality of life in patients of melasma. J Pakistan Assoc Dermatol. 2013;23(2):143-8.

24. Levy J-L, Pons F, Agopian L, Piccardi N, De Belilovsky C, Chadoutaud B, et al. Effectiveness of a new depigmenting trio, Melanex® Trio in melasma: clinical and biometrological results, quality of life, image analysis. Nouv Dermatol. 2006;25(4):319-29.

25. Arellano I, Cestari T, O Campo-Candiani J, Azulay-Abulafia $L$, Trindade Neto PB, Hexsel D, et al. Preventing melasma recurrence: prescribing a maintenance regimen with an effective triple combination cream based on longstanding clinical severity. J Eur Acad Dermatol Venereol. 2012;26(5):611-8. doi: 10.1111/j.1468-3083.2011.04135.x

26. Miot LDB, Miot HA, Silva MG, Marques MEA. Morphological and functional comparative study of melanocytes in melasma lesions. An Bras Dermatol. 2007;82(6):529-34. doi: 10.1590/s0365-05962007000600005

27. Vachiramon $V$, Suchonwanit $P$, Thadanipon K. Melasma in men. J Cosmet Dermatol. 2012;11(2):151-7. doi: 10.1111/j.1473-2165.2012.00613.x

28. Cestari TF, Hexsel D, Viegas ML, Azulay L, Hassun K, Almeida ART, et al. Validation of a melasma quality of life questionnaire for Brazilian-Portuguese language: the MELASQOI-BP study and improvement of QoL of melasma patients after triple combination therapy. $\mathrm{Br}$ J Dermatol. 2006;156(1):13-20. doi: 10.1111/j.13652133.2006.07591.x 